\title{
Evaluation of antioxidant and anti- inflammatory potency of Lepidium pinnatifidum Ledeb
}

\author{
Saira Bibi, Munazza Anwar, Huma Farooque Hashmi and Muhammad Rashid Khan
}

\begin{abstract}
Backgroound: Lepidium pinnatifidum is a multipurpose, beneficial plant and known well for its indigenous therapeutic standards. Current study is aimed to investigate antioxidant and anti-inflammatory potency of Lepidium pinnatifidum.

L. pinnatifidum dried powder was extracted with crude methanol (LPM) and then fractionated with various solvents to get respective fractions, termed as, $n$-hexane $(L P H)$, chloroform $(L P C)$, ethyl acetate $(L P E)$, butanol $(L P B)$ and the aqueous fraction (LPA). Fractions were evaluated for total flavonoid and phenolic content. Antioxidant profile was quantified via an array of antioxidant assays. Anti inflammatory activity was evaluated in vitro, and further assessed by in vivo study in Sprague Dawley rat.

Result: Total phenolics (TPC) range from $48.15 \pm 1.03-241.23 \pm 1.07 \mathrm{mg}$ GAE/g while total flavonoids (TFC) quantified were $16.32 \pm 1.14-136.32 \pm 1.14 \mathrm{mg} \mathrm{RE} / \mathrm{g}$. The in vitro antioxidant assays exhibited remarkable radicals scavenging action in different assays. Substantial positive correlation was instituted between TPC, TFC and various antioxidant assays. Inhibition of the heat induced protein denaturation reflected anti inflammatory potency, further supported by in vivo carrageenan induced paw edema.
\end{abstract}

Conclusion: The obtained results lead to suggesting the therapeutic perspective of L. pinnatifidum in oxidative stress and inflammation associated ailments. The bio active ingredients behind its potential protectivity needs to be further confirmed.

Keywords: Lepidium pinnatifidum, Anti-inflammatory, Antioxidant, Flavonoids, Phenolics

\section{Background}

The grounds of the poisonous possessions of $\mathrm{O}_{2}$ were obscure really, before the free radical theory of $\mathrm{O}_{2}$ toxicity of Gershman, which describes that toxicity of $\mathrm{O}_{2}$ is because of partly reduced oxygen species. Free radicals have instable and reactive lone electron in their outer shell that can make them to strike specific biomolecules [1]. In human body, two little rascal species explicitly reactive oxygen and reactive nitrogen species are responsible of oxidative stress in the various pathophysiological conditions [2]. Continued oxidative stress may result in

\footnotetext{
* Correspondence: Sairabibi350@gmail.com

Department of Biochemistry, Quaid I Azam university, Islamabad, Pakistan
}

eternal damage to the vital organs of body, that could ultimately lead to the chronic disorders and premature aging $[3,4]$. Antioxidants are species that quench or inhibit free radical bioreactions as well as delay or inhibit cellular damage [5].

Inflammation is considered as multifaceted biological reaction in response to injurious stimuli like pathogens, damaged tissues and irritants. However, inflammatory progressions also lead to the onset or maintains of severe disorders [6]. Despite the arsenal of current medications, therapeutics is often not effective enough or intolerable side effects hampered the progress. Thus, discovering new anti inflammatory compounds still own a great demand on researchers in academia and industry.

\section{Springer Open}

(- The Author(s). 2020 Open Access This article is licensed under a Creative Commons Attribution 4.0 International License, which permits use, sharing, adaptation, distribution and reproduction in any medium or format, as long as you give appropriate credit to the original author(s) and the source, provide a link to the Creative Commons licence, and indicate if changes were made. The images or other third party material in this article are included in the article's Creative Commons licence, unless indicated otherwise in a credit line to the material. If material is not included in the article's Creative Commons licence and your intended use is not permitted by statutory regulation or exceeds the permitted use, you will need to obtain permission directly from the copyright holder. To view a copy of this licence, visit http://creativecommons.org/licenses/by/4.0/. 
Inflammation and pain consider as common illness in society associated with many other diseases [7]. Inflammation basically enhance pain by causing damage to pain receptors result in abnormal functioning [8].

Lepidium pinnatifidum Ledeb. a member of Brassicaceae family, is found in central Asia and Europe. Its leaves and seeds both are known to have medicinal values. L. pinnatifidum is used in many populations as an alleviator in constipation. It is well known for its positive effects in piles. Seeds of this herb are very effective in painful menstruation in women [8]. Its leaves are cooked as nutritious vegetable, which reflects its non toxic nature. The current study was designed to investigate anti oxidative and anti inflammatory potential of $L$. pinnatifidum.

\section{Methods}

\section{Plant collection}

L. pinnatifidum whole plant was collected from Bagh, Azad Jammu and Kashmir, identified from Dr. Zafar, department of Plant sciences, Quaid i Azam university (QAU) Islamabad, and 175,701 accession number was assigned from herbarium of Pakistan, QAU Islamabad.

\section{Preparation of extract and fractionation}

The whole plant was wiped properly and dried under shade. Two kilo gram ground plant material was soaked in the methanol for 7 days and filtered, filtrate termed as LPM. Next was fractionation to separate plant's compounds, from the crude extract, according to their polar contents. $50 \mathrm{~g}$ of crude extract was mixed in $200 \mathrm{~m}$ litre distilled water. $n$-hexane $\left(\mathrm{C}_{6} \mathrm{H}_{6}\right)$, chloroform $\left(\mathrm{CHCl}_{3}\right)$, ethyl-acetate $\left(\mathrm{C}_{4} \mathrm{H}_{8} \mathrm{O}_{2}\right)$ and butanol $\left(\mathrm{C}_{4} \mathrm{H}_{9} \mathrm{OH}\right)$ were added correspondingly to obtain respective fractions. At the end, residues left in separating funnel, were termed as aqueous fraction. All the fractions were collected, evaporated, quantified and finally kept at $4{ }^{\circ} \mathrm{C}$ for further use.

\section{Quantitative phytochemicals analysis Total phenolic content}

Total phenolics present in plant fractions were investigated by using Folin Ciocalteu methodology [9]. $1 \mathrm{ml}$ of plant fraction dissolved in methanol was added in $1.5 \mathrm{ml}$ of Folin ciocalteu reagent, diluted up to 10 folds. Then $1.2 \mathrm{ml}$ of $7.5 \% \mathrm{Na}_{2} \mathrm{CO}_{3}$ was mixed and mixture was placed at $27^{\circ} \mathrm{C}$ for $90 \mathrm{~min}$. The absorbance of mixture was checked by using ultraviolet-visible spectrophotometer, at wavelength of $760 \mathrm{~nm}$. Using gallic acid as standard molecule, result articulation was done as milli gram equivalent of gallic acid.

\section{Total flavonoids content}

The content of total flavonoids was evaluated by following aluminium chloride $\left(\mathrm{AlCl}_{3}\right)$ colorimetric method used by Baba and Malik [10]. One milli litre of plant fractions (one $\mathrm{mg} / \mathrm{ml}$ ethanol) were assorted thoroughly with four milli litre distilled $\mathrm{H}_{2} \mathrm{O}$ and $0.3 \mathrm{ml}$ of sodium carbonate (5\%) solution respectively, then after $5 \mathrm{~min}$ of incubation, $0.3 \mathrm{ml}$ aluminium chloride solution (10\%) was put in the mixture and placed for $6 \mathrm{~min}$. At last 1 mol/l sodium hydroxide solution was put in, and final volume was raised up to $10 \mathrm{ml}$ by addition of distilled $\mathrm{H}_{2} \mathrm{O}$. After $15 \mathrm{~min}$, absorbance was reserved at $510 \mathrm{~nm}$ in Ultraviolet - Visible spectrophotometer. The TPC was measured by calibration curve using standard values of rutin. Results were articulated as mg rutin per gram equivalents dry weight.

\section{In vitro antioxidant assessment \\ DPPH (1, 1-diphenyl-2-picryl-hydrazyl) radicals scavenging assay}

Scavenging DPPH by plant fractions was measured by procedure used by Alam et al. [11] Stock solution was set by using $100 \mathrm{ml}$ methanol and adding $24 \mathrm{mg}$ of $\mathrm{DPPH}$ in it, this solution was placed at $20^{\circ} \mathrm{C}$. Optical density of this solution was measured and maintained at 0.908 ( \pm 0.02 ), at $517 \mathrm{~nm}$, by using methanol to dilute stock solution. 100 micro litre plant sample and $900 \mu \mathrm{l}$ of DPPH solution were mixed thoroughly and incubated for about $15 \mathrm{~min}$ in dark, at $37^{\circ} \mathrm{C}$. In ultraviolet-visible spectrophotometer absorbance was taken at $517 \mathrm{~nm}$. The ascorbic acid was positive control and antioxidant potential was calculated by formula given in eq. 1 .

Scavenging effect $(\%)=\frac{[\text { control absorbance }- \text { sample absorbance }]}{[\text { control absorbance }]} \times 100$

\section{Hydroxyl free radicals scavenging assay}

Scavenging ability of free hydroxyl radical was examined by Choi et al. methodology [12]. To do so following procedure was carried out. $500 \mu \mathrm{l}$ deoxyribose $(2.8 \mathrm{mM})$ was mixed in phosphate buffer $(50 \mathrm{mM})$ having $\mathrm{pH}$ value of 7.4, $200 \mu \mathrm{l}$ of $100 \mathrm{mM} \mathrm{FeCl}$ and $100 \mu \mathrm{l}$ EDTA $(0.1 \mathrm{M})$ was put in reaction mixture. Next, $100 \mu$ l hydrogen per oxide $(200 \mathrm{mM})$ and plant sample $(100 \mu \mathrm{l})$ are added.

Volume of 100 micro litre ascorbic acid $300 \mathrm{mM}$ was put in reaction mixture and allowed to incubate at room temperature for $60 \mathrm{~min}$. Then one $\mathrm{ml}, 2.8 \% \mathrm{TCA}$ and one $\mathrm{ml}, 10 \% \mathrm{w} / \mathrm{v}$ TBA prepared in sodium hydroxide $(50 \mathrm{mM})$ was mixed and placed in water bath for 15 min. On cooling, $532 \mathrm{~nm}$ wavelength was used to measure optical density. Radical neutralizing power was quantified using given formula. 


$$
\begin{aligned}
\text { Scavenging Activity }(\%)= & \frac{[1-\text { Sample Absorbance }]}{[\text { Control Absorbance }]} \\
& \times 100
\end{aligned}
$$

\section{Nitric oxide scavenging assay}

Scavenging potential of each fraction was assessed by procedure used by Anu and Usha [13]. It was done by taking sodium nitroprusside $(100 \mu \mathrm{l}, 10 \mathrm{mM})$ in saline phosphate buffer and intermixed with plant sample $(100 \mu \mathrm{l})$. Sodium-nitroprusside generate nitric oxide radicals that interact with oxygen and give rise to nitrite ion specie, which can be detected by Griess reagent. After 3 $\mathrm{h}$ of incubation $1 \mathrm{ml}$ of Griess reagent was added. Griess reagent is made by taking equal volume of sulfanilamide $(1 \%)$ in phosphoric acid (5\%) and naphthylethylene diamine di-hydrochloride $(0.1 \%)$ in distilled water. The absorbance was taken at $546 \mathrm{~nm}$ in UV - Visible spectrophotometer. Scavenging power was measured by formula given in equation one.

\section{Chelating power assay}

Aptitude of chelating iron (II) of plant fractions was assessed by following Karatoprak et al. [14] Plant samples were mixed in methanol and serial dilutions were made. $200 \mu \mathrm{l}$ of plant aliquot was blended with methanol $(900 \mu \mathrm{l})$ plus $\mathrm{FeCl}_{2} \cdot 2 \mathrm{H}_{2} \mathrm{O}(100 \mu \mathrm{l}, 2 \mathrm{mM})$ and incubated for $5 \mathrm{~min} .400 \mu \mathrm{l}$ ferrozine $(5 \mathrm{mM})$ was put in reaction solution and left to incubate for $10 \mathrm{~min}$. By using UV Visible spectrophotometer absorbance was read at 562 $\mathrm{nm}$ wavelength Chelating potency was quantified by using formula given in equation one.

\section{Reducing power assay}

Protocol of Phatak and Hendre was trailed to determine reducing activity of plant fractions [15]. About $2 \mathrm{ml}$ plant sample is mixed in $2 \mathrm{ml}$ phosphate buffer $(0.2 \mathrm{M})$ of $\mathrm{pH}$ 6.5. Volume of $2 \mathrm{~m}$ litre potassium ferricyanide $(10 \mathrm{mg} / \mathrm{l})$ is added in mixture. After $20 \mathrm{~min}$ incubating at fifty degree centigrade, trichloroacetic acid (2 ml, 10\%) was mixed in it. Then centrifugation was done at 3000 rpm speed for $10 \mathrm{~min}$. After centrifugation $2 \mathrm{~m}$ litre supernatant was taken gently and diluted by adding two milli litre D. $\mathrm{W}$ and $0.5 \mathrm{ml}(0.1 \%) \mathrm{FeCl}_{3}$. After $10 \mathrm{~min}$, UV-Visible spectrophotometer was used to take absorbance at $700 \mathrm{~nm}$. And gallic acid was standard in this assay.

\section{Phosphomolybdenum assay}

Antioxidant potency of plant fractions was evaluated by phospho-molybdenum assay by Hossain and Shah [16]. In eppendorf $100 \mu \mathrm{l}$ of plant aliquots were allowed to mix with $1000 \mu \mathrm{l}$ of reagent containing sodium phosphate (28 $\mathrm{mM}), 4 \mathrm{mM}$ of ammonium molybdate $\left[\left(\mathrm{NH}_{4}\right)_{2} \mathrm{MoO}_{4}\right]$ and sulfuric acid $(0.6 \mathrm{M})$. After mixing eppendorfs were incubated in water bath at $90^{\circ} \mathrm{C}$ for $90 \mathrm{~min}$, to prevent direct exposure of light eppendorfs were covered by aluminium foil. After incubation, the reaction mixture is allowed to cool at normal temperature and absorbance was taken at 765 nano meters. Ascorbic acid was proceeded as a standard.

\section{B-carotene bleaching assay}

Antioxidant dimension of plant's fractions was determined by betacarotene bleaching methodology used by Hatami et al. [17] Amount of two milli gram $B$ carotene was added in chloroform $(10 \mathrm{ml})$ to make $\beta$ carotene solution. $200 \mathrm{mg}$ of Tween 80 and linoleic acid were added in this solution and chloroform was evaporated from it. Volume of $50 \mathrm{ml}$ of D. W was mixed in reacting mixture and vortexed strongly to have a uniformed emulsion made by $\beta$ carotene linoleate. Volume of $250 \mu \mathrm{l}$ of that emulsion was taken and mixed with $30 \mu \mathrm{l}$ plant sample $(30 \mu \mathrm{l})$. Immediately optical density was checked at 470 $\mathrm{nm}$. For $2 \mathrm{~h}$ mixtures were placed at $45^{\circ} \mathrm{C}$ in water bath and absorbance was read again. In this assay catechin served as a standard.

Bleaching inhibition $\%=[\{\mathrm{AA}(120)-\mathrm{AC}(120)\} /\{\mathrm{AC}(0)-\mathrm{AC}(120)\}] \times 100$

Here, $A_{A}(120)$; sample absorbance on $120 \mathrm{~min}, \mathrm{AC}_{(120)}$ and $\mathrm{A}_{\mathrm{C}}(0)$; control absorbance on 120 and $0 \mathrm{~min}$ respectively.

\section{In vitro anti-inflammatory assay}

Anti-inflammatory potency was calculated in accordance to the protocol of Kulkarni et al. [8]. Reaction blend comprising of test sample and aqueous soln. of bovine albumin (1\%) was incubated at $37{ }^{\circ} \mathrm{C}(20 \mathrm{~min})$ and then at $51{ }^{\circ} \mathrm{C}(20 \mathrm{~min})$. Absorbance was measured at $660 \mathrm{~nm}$ using spectrophotometer. Loprin was standard drug used and test was performed in triplicate. Following formula used to determine inhibition percentage of protein denaturing.

Inhibition of $\%$ denaturation $=[$ Abs of Control-Abs of sample $/$ Abs of control $] \times 100$

\section{In vivo studies}

Sprague-Dawley rats of both sexes were of almost 6 weeks old rats about $150-200 \mathrm{~g}$ weight maintained at standardized laboratory conditions at primate facility of the QAU, Islamabad. Rats had ad libitum access to water and basal chow. Ethical Committee of QAU, Islamabad permitted study design, for animal's care and experimentation. 


\section{Acute-toxic studies}

Female Sprague Dawley rats (Rattus novergicus) weighted $150 \mathrm{~g}$ - $180 \mathrm{~g}$ were separated in 3 groups, randomly, 3 rats in each. Rats were administered orally with LPM, LPH, LPC, LPE, LPB and LPA at varied doses $(250 \mathrm{mg} / \mathrm{kg}, 500 \mathrm{mg} / \mathrm{kg}$, $1000 \mathrm{mg} / \mathrm{kg}, 2000 \mathrm{mg} / \mathrm{kg}, 3000 \mathrm{mg} / \mathrm{kg}$ and $4000 \mathrm{mg} / \mathrm{kg}$ ) in the morning. The animals were observed for any change in physical appearance, irregular behaviour and mortality after 30 min for $6 \mathrm{~h}$ then after $24 \mathrm{~h}$ for 15 days. Given doses did not produce any behavioural irregularity or mortality.

\section{Anti inflammatory activity}

To find out the anti inflammatory potency of plant, carrageenan mediated hind paw edema was trailed in this study [18]. Male Sprague-Dawley rats (150-200 g) were separated randomly in to 15 groups; each containing 7 animals. Volume of normal paw was measured before experimentation. Group I was given saline (1\%) and diclofenac potassium $(10 \mathrm{mg} / \mathrm{kg})$ was given to Group-II. Animals of remaining groups were treated with plant fraction dosage of 10,200 , and $400 \mathrm{mg} / \mathrm{kg}$ at fasting.
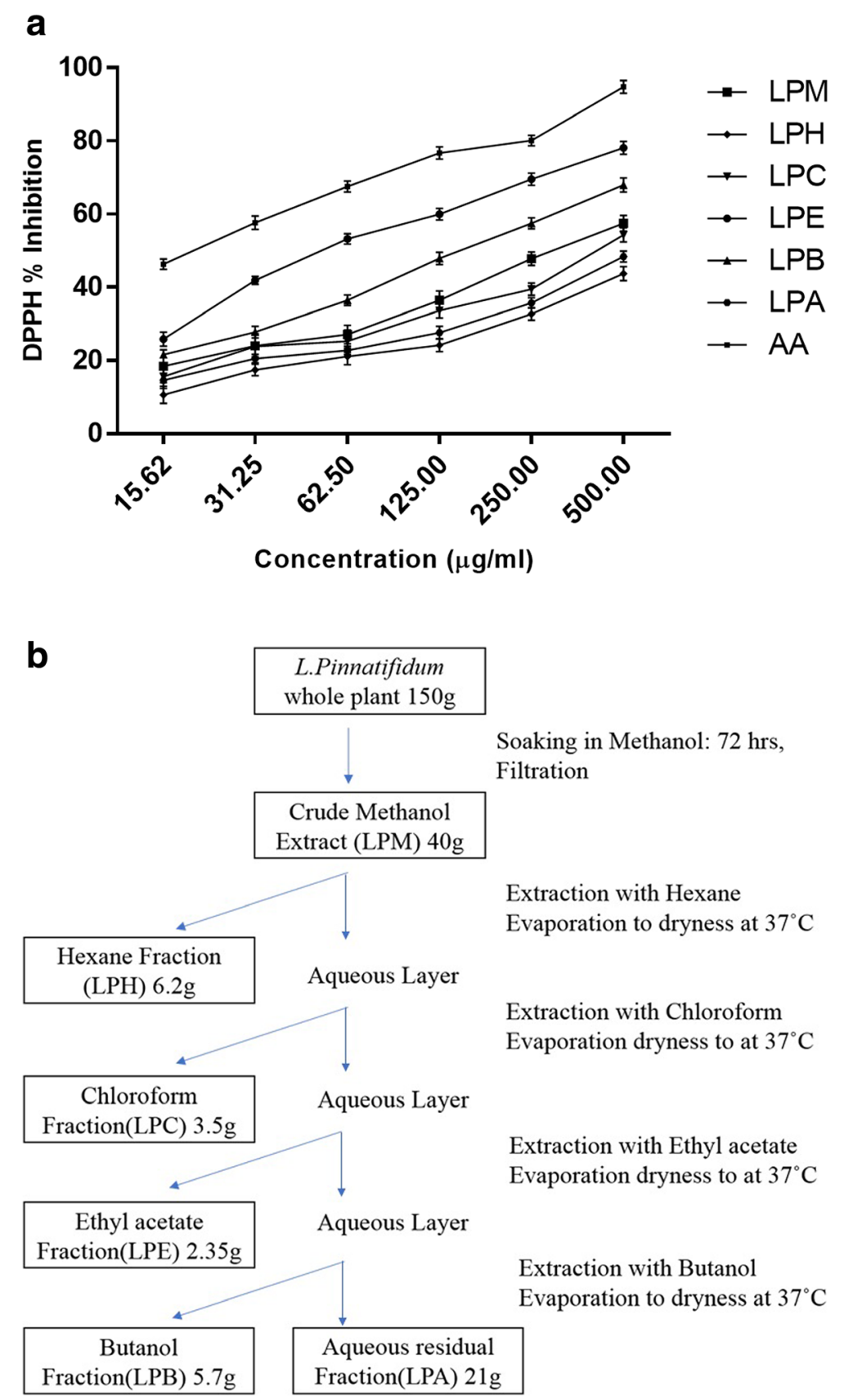

Fig. 1 Fractionation chart of L. pinnatifidum 
Carrageenan $1 \mathrm{ml} / \mathrm{kg}$ ( $1 \%$ in saline $\mathrm{w} / \mathrm{v})$ was injected in hind paw, about $30 \mathrm{~min}$ earlier to dose administration. Digital plethysmometer was used to measure paw volume instantly after injecting carrageenan $(0 \mathrm{~h})$ and repeated after every $1 \mathrm{~h}$ up to $4 \mathrm{~h}$. Paw edema volume of each rat was calculated and percentage inhibition of every groups was measured.

$$
\mathrm{EV}=\mathrm{PVA}-\mathrm{PVI}
$$

EV; edema volume, PVI; initial paw volume, PVA; paw volume after injecting carrageenan

$$
\text { Edema inhibition } \%=\frac{E V c-E t}{E V c} \times 100
$$

EVc; Control group edema volume, EVt; Sample group edema volume.

\section{Statistical analysis}

Whole data is presented as mean \pm SD. In vitro analysis contained triplicate evaluation while seven animals were used for each in vivo group. The Graph Pad Prism 5 was used for in vitro activities, for assessing correlation and $\mathrm{IC}_{50}$. Statistix 8.1 (1-way analysis of variance) was used for in vivo investigation. Observed significance level was $p \leq 0.05$ for in vitro and $p \leq 0.01$ for the in vivo analysis.

\section{Results}

The $50 \mathrm{~g}$ yield was obtained from $1.5 \mathrm{~kg}$ whole plant powder of the L. pinnatifidum by commercial methanol extraction procedure. An amount of $40 \mathrm{~g}$ of total methanolic extract, labelled as LPM, was fractionated via liquid-liquid partition in ascending order of polarity of different solvents. Various solvents exhibited following order during fractionation: LPA $>$ LPH $>$ LPB $>$ LPC $>$ LPE as shown in Fig. 1b.

\section{Quantitative analysis}

Evaluation of phenolic and flavonoid contents

LPE exhibited maximum quantity of phenolics (241.23 \pm $1.07 \mathrm{mg}$ GAE/g dry extract) followed by LPB (197.28 \pm $1.11 \mathrm{mg}$ GAE/g dry extract as Table 1 is illustrating. LPC found to have $161.29 \pm 0.61$, LPA $129.09 \pm 1.01$ and LPH fraction $48.152 \pm 1.03 \mathrm{mg}$ GAE/g dry extract of phenolics. Likewise, LPE fraction is found to be rich in flavonoids followed by LPB, LPM, LPC, LPA and LPH as shown in Table 1.

\section{DPPH radicals scavenging activity}

Values for $\mathrm{IC}_{50}$ of DPPH radical quenching activity of $L$. pinnatifidum fractions are shown in Table 2. Finest values for $\mathrm{IC}_{50}$ is exhibited by $\operatorname{LPE}(62.703 \pm 2.1 \mu \mathrm{g} / \mathrm{ml})$. Overall, order of $\mathrm{IC}_{50}$ of $\mathrm{LPE}<\mathrm{LPB}<\mathrm{LPC}<\mathrm{LPC}<\mathrm{LPA}<$ $\mathrm{LPH}$ is observed. Concentration dependent activity is observed as shown in Fig. 1a.

\section{Hydroxyl radicals scavenging assay (HRS)}

In this assay, all fractions of $L$. pinnatifidum quenched - $\mathrm{OH}$ radicals and halted 2- deoxyribose breakdowns. A concentration dependent pattern is noticed for hydroxyl radical scavenging activity (Fig. 2). Lowermost $\mathrm{IC}_{50}$ values are shown by LPE. Overall pattern of LPE > LPB > $\mathrm{LPM}>\mathrm{LPC}>\mathrm{LPA}>\mathrm{LPH}$ for hydroxyl radical quenching activity is noticed (Table 2).

\section{Nitric oxide scavenging assay}

In this study, the lowermost $\mathrm{IC}_{50}$ value for nitric oxide foraging action is recorded by $\operatorname{LPE}(276 \pm 1.9 \mu \mathrm{g} / \mathrm{ml})$. $\mathrm{IC}_{50}$ value for another fraction LPA and LPH is; $(534.27 \pm 1.9 \mu \mathrm{g} / \mathrm{ml})$ and $(610.34 \pm 2.4 \mu \mathrm{g} / \mathrm{ml})$ respectively as revealed in Table 2. The dose dependant pattern of percentage inhibition as shown in Fig. 3.

\section{Iron chelating activity}

The iron chelating action of $L$. pinnatifidum fractions was assessed. $\mathrm{IC}_{50}$ values are given in Table 2 . Our study showed LPE as best chelating potential of iron ions, followed by LPM and LPB. The percentage inhibition of various fractions is shown in Fig. 4.

\section{Reducing power assay}

LPE exhibited maximum reducing power with $987.97 \mathrm{mg}$ ascorbic acid equivalent/g sample measured at $250 \mu \mathrm{g} /$ $\mathrm{ml}$ of extract concentration, as illustrated in Fig. 5. It

Table 1 Total flavonoid and phenolic contents of L. pinnatifidum

\begin{tabular}{lll}
\hline Plant sample & TP (mg GA eqv. /g dry sample) & TF (mg rutin eqv. /g dry sample) \\
\hline LPM & $182.23 \pm 1.07^{\mathrm{c}}$ & $95.27 \pm 1.10^{\mathrm{c}}$ \\
LPH & $48.15 \pm 1.03^{\mathrm{f}}$ & $16.32 \pm 1.14^{\mathrm{f}}$ \\
LPC & $161.29 \pm 0.61^{\mathrm{d}}$ & $86.74 \pm 1.56^{\mathrm{d}}$ \\
LPE & $241.42 \pm 1.07^{\mathrm{a}}$ & $136.32 \pm 1.14^{\mathrm{a}}$ \\
LPB & $197.28 \pm 1.11^{\mathrm{b}}$ & $110.03 \pm 1.00^{\mathrm{b}}$ \\
LPA & $129.08 \pm 1.01^{\mathrm{e}}$ & $49.06 \pm 1.06^{\mathrm{e}}$
\end{tabular}

Each value is represented as mean \pm SD $(n=3)$. Means with different superscript $\left(^{\mathrm{a}-f}\right)$ letters in the rows are significantly $(p<0.05)$ different from one another. TF; Total flavonoids, TP; total phenolics, eqv; equivalent 
Table $2 \mathrm{IC}_{50}$ values of different antioxidant activities of $L$. pinnatifidum fractions

\begin{tabular}{|c|c|c|c|c|c|}
\hline Plant sample & DPPH scavenging & Hydroxyl scavenging & Nitric Oxide & Iron chelating & $\beta$-Carotene \\
\hline LPM & $306.6 \pm 2.8^{d}$ & $475.33 \pm 2.6^{d}$ & $445.23 \pm 1.4^{d}$ & $466.1 \pm 2.5^{d}$ & $314.53 \pm 1.9^{d}$ \\
\hline LPH & $733.3 \pm 2.1^{a}$ & $>1000^{a}$ & $610.63 \pm 2.4^{\mathrm{a}}$ & $896.13 \pm 1.8^{\mathrm{a}}$ & $516.56 \pm 2.5^{a}$ \\
\hline LPC & $456.5 \pm 2.7^{c}$ & $614.4 \pm 2.7^{c}$ & $484.8 \pm 2.4^{c}$ & $546.6 \pm 2.06^{c}$ & $352.33 \pm 2.7^{c}$ \\
\hline LPE & $62.70 \pm 2.1^{f}$ & $146.3 \pm 2.5^{f}$ & $276.3 \pm 1.9^{f}$ & $236.3 \pm 1.4^{f}$ & $95.93 \pm 2.19^{f}$ \\
\hline LPB & $147.4 \pm 2.3^{\mathrm{e}}$ & $253.04 \pm 2.3^{e}$ & $372.8 \pm 1.6^{\mathrm{e}}$ & $374.86 \pm 1.7^{e}$ & $119.5 \pm 1.96^{\mathrm{e}}$ \\
\hline LPA & $714.1 \pm 2^{b}$ & $954.13 \pm 2.0^{b}$ & $534.7 \pm 1.9^{b}$ & $778.46 \pm 2.4^{b}$ & $445.2 \pm 2.3^{b}$ \\
\hline Rutin & - & $41.09 \pm 1.5^{\mathrm{g}}$ & - & - & - \\
\hline AA & $21.06 \pm 1.5^{\mathrm{g}}$ & - & $155.13 \pm 2.2^{g}$ & - & - \\
\hline Gallic & - & $61.24 \pm 0.06^{h}$ & - & - & - \\
\hline \multicolumn{6}{|l|}{ acid } \\
\hline EDTA & - & - & - & $151.1 \pm 2.4^{9}$ & - \\
\hline Catechin & - & - & - & - & $60.75 \pm 0.88^{9}$ \\
\hline
\end{tabular}

Values are presented as the means $\pm \mathrm{SD}(n=3)$. Means with different superscript $\left.{ }^{(\mathrm{a}-\mathrm{g}}\right)$ letters in the rows are significantly $(p<0.05)$ different from one another. AA; Ascorbic acid

was followed by LPB (943.81 mg) and LPM (918.70 mg). Correlation is highly significant with both TPC $\left(\mathrm{R}^{2}=\right.$ $\left.0.9119^{* *}\right)$ and TFC $\left(R^{2}=0.9775^{* * * *}\right)$ shown in Table 3.

\section{Phosphomolybdenum assay}

Plant fractions were evaluated for total antioxidant ability by phosphomolybdate assay. Antioxidant capacity was exhibited as ascorbic acid equivalent ( $\mathrm{mg} / \mathrm{g}$ extract). LPE showed maximum antioxidant potency and LPH showed least. Different fractions exhibited antioxidant potential in following order LPE $>\mathrm{LPB}>\mathrm{LPM}>\mathrm{LPC}>$ LPA > LPH, exhibited in Fig. 6.

\section{$\beta$-Carotene scavenging activity}

LPE exhibits lowest value of $\mathrm{IC}_{50}(95.93 \pm 2.19 \mu \mathrm{g} / \mathrm{ml})$ as equated to remaining fractions. Catechin was used as standard and exhibited $\mathrm{IC}_{50} 60.75 \pm 0.88 \mu \mathrm{g} / \mathrm{ml}$ as given

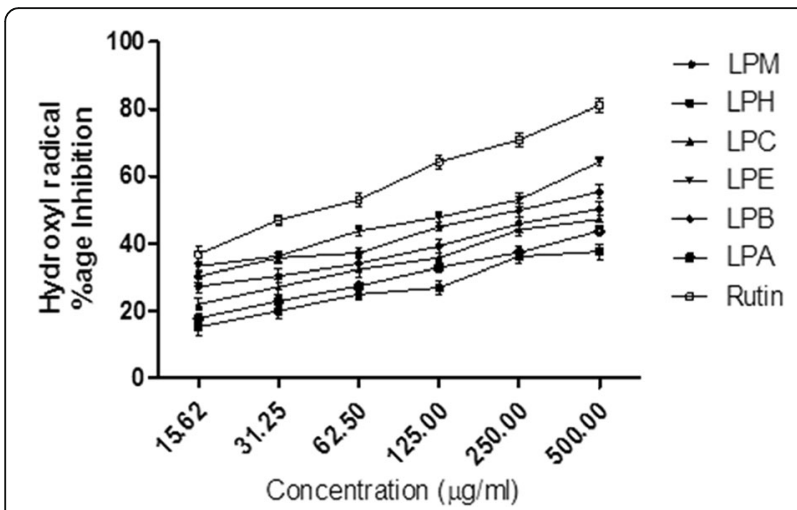

Fig. 2 Hydroxyl radical assay of L. pinnatifidm methanol extract and its fractions in Table 2. Bleaching power is dependent on concentration of sample and observed activity is shown in Fig. 7.

\section{Correlation studies}

Antioxidant potency determined through various assays and executed $\mathrm{IC}_{50}$ values $(\mu \mathrm{g} / \mathrm{ml})$ were used to find out their correlation with TPC and TFC. All assays showed substantially positive correlation with the TFC and TPC. Hydroxyl scavenging assay exhibited highly significant correlation with total phenolic content $\left(R^{2}=0.9453^{* * *} p<0.001\right)$ and total flavonoid content $\left(\mathrm{R}^{2}=0.9677^{* * * *} \mathrm{p}<0.001\right)$. Reducing power, Iron chelating and nitric oxide assay showed more significant correlation with total flavonoid content $(\mathrm{p}<$ $0.001)$, as shown in Table 3.

\section{In vitro anti inflammatory activity}

The anti-inflammatory activity of $L$. pinnatifidum methanol extract and its fractions was estimated in vitro through inhibiting capacity of albumin denaturation. All fractions were vigorous in the inhibiting heat mediated albumin denaturation at various concentrations as given in Table 4 . $\mathrm{IC}_{50}$ value in order $\mathrm{LPH}>\mathrm{LPE}>\mathrm{LPM}>\mathrm{LPC}>\mathrm{LPB}$ and LPA also showed inhibition of protein denaturation.

\section{Estimation of acute toxicity}

Methanol extract of L. pinnatifidum found nontoxic at all the tested doses and did not show any deadly sign in rats. No morbidity and mortality were detected.

\section{In vivo bioassays}

\section{Anti inflammatory potential}

In vivo anti inflammatory capacity by method of carrageenan provoked paw edema demonstrated in the Table 5. Current study proposed that anti inflammatory 


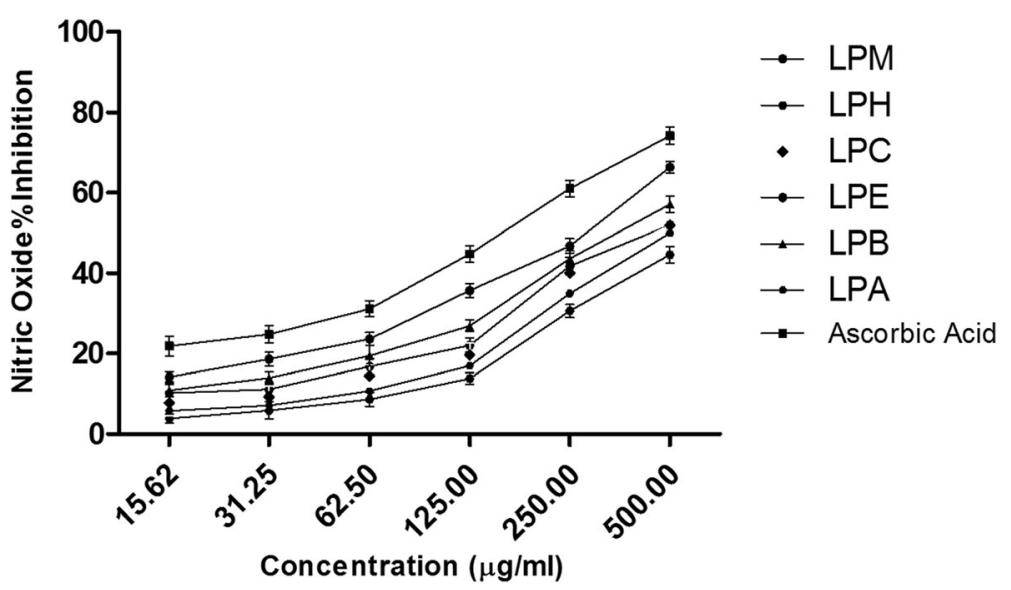

Fig. 3 Nitric oxide radical scavenging assay L. pinnatifidm methanol extract and its fractions

capacity of different used fractions was time dependent and it turn to maximum after 3rd h. Results indicated that LPH and LPE revealed significant anti-inflammatory activity and also exhibited substantial decrease in \%age edema at 2 nd, 3rd and 4th hour relative to all other fractions. LPH and LPE at $400 \mathrm{mg} / \mathrm{kg}$ concentration showed significant activity close to diclofenac potassium. LPB and LPC fractions also slightly inhibited the edema development. After 1st hour of carrageenan administration various fractions displayed edema inhibition in the following order LPH $>\mathrm{LPE}>\mathrm{LPM}>\mathrm{LPC}>\mathrm{LPB}$ and LPA at $400 \mathrm{mg} / \mathrm{kg}$ concentration.

\section{Discussion}

Synthetic medication has many deleterious side effects on human body, that's why new era is being shifted towards natural therapeutic system for curing various disorders. Antioxidants are key players in the prevention of several diseases. There is increased demand of natural products derived antioxidants because of their protective capacity against illness. Phenolics are bio-active compounds which account for a wide array of

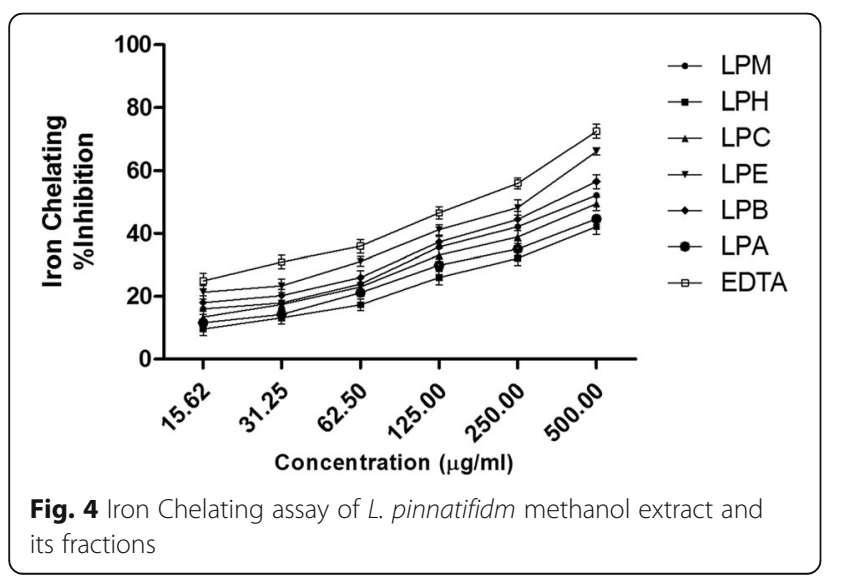

pharmacological actions including anti-oxidant, sedating, anti-inflammatory, wound-healing as well as antimicrobial properties [19]. Among these properties, antioxidant potential, particularly, depends on number and orientation of hydroxyl groups in the phenolics. Phenolic antioxidants donate one or more $\mathrm{H}$ - atoms to lipid radicals to produce lipid derivatives and other radical species which are relatively more stable and quite less available to initiate autoxidation [20]. Folin Ciocalteu technique to investigate total phenolic contents is based on the formation of coloured product by molybdo-tungstophosphoric reagent mediated oxidation of phenol. Total phenolic contents in ethyl acetate fraction were highest among other fractions, while $n$-hexane showed least which is in accordance to many other studies. The highest $(78.9 \pm 1.7 \mathrm{mg} \mathrm{GAE} / \mathrm{g})$ total phenolic contents, in Carissa opaca fruits, was noted in LPE, ethyl acetate extract while $n$-Hexane fraction $(25.8 \pm 2.8)$ showed lowest TPC [21].

Flavonoids are present in mesophyll's nuclei and within ROS generating centres. Flavonoids are major contributors in plant's pigments and well known for cytotoxic, antimicrobial and antioxidant activities. To determine total flavonoid content, aluminium chloride chlorimetric method is used in which a stable complex is formed between $\mathrm{AlCl}_{3}$, keto and $\mathrm{OH}^{-}$group of flavonoid molecules. The ethyl acetate extract showed highest flavonoid content, while hexane extract was least rich in flavonoids. In another study methanolic extract (48.54 \pm $2.9 \mathrm{mg} \mathrm{RE} / \mathrm{g}$ ) of Monotheca buxifolia fruit showed highest flavonoid contents while lowest $4.110 \pm 0.51$ was shown by hexane fraction (Jan et al., 2013) [22].

To find out the antioxidant ability of L. pinnatifidum series of antioxidant assays was carried out. DPPH radical stabilizing activity is one of crucial assessment of antioxidant potentcy of pure compounds or crude plant extract [23]. DPPH, a violet coloured crystalline powder, 


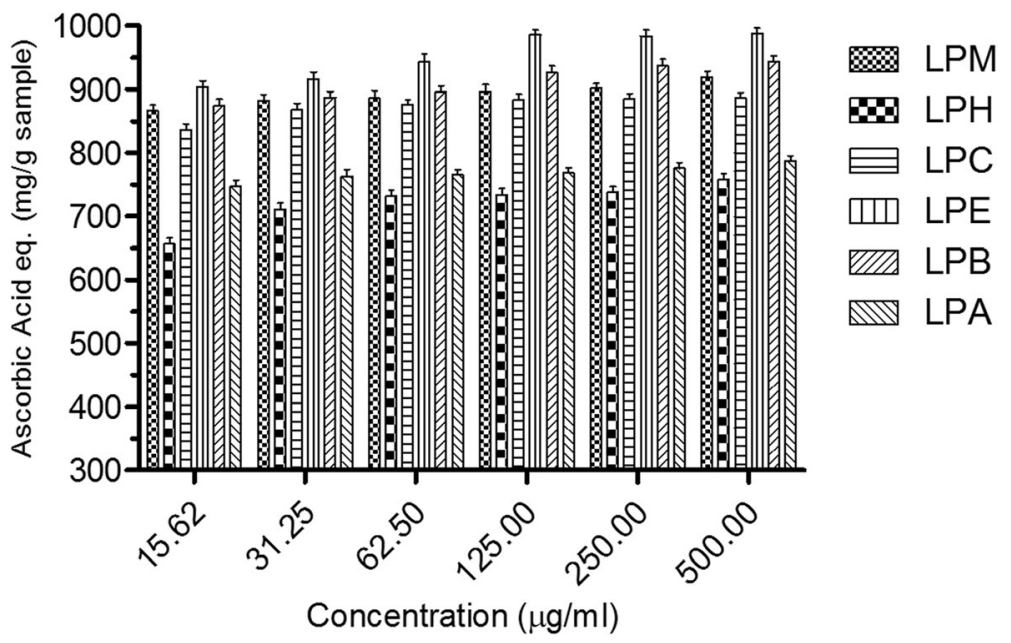

Fig. 5 Reducing assay of L. pinnatifidm methanol extract and its fractions

change its colour from purple to yellow on reduction. Extent of colour alteration depends on scavenging action of pure compound or antioxidants present in crude extract [24]. Scavenging potential of plant is the characteristic of phenolics and flavonoids present in plant. In general, polar solvents like ethyl acetate are rich in flavonoids and phenolic contents and exhibit good scavenging potential. L. pinnatifidum ethyl acetate fraction displayed maximum scavenging ability against DPPH.

Hydroxyl radical is a powerful reactive oxygen specie present in living systems, interacting with several polyunsaturated molecules of cellular membrane causing harm to living cells [25]. HRS assay is aimed to find out scavenging activity of free $\mathrm{OH}$ radicals in presence of various concentrations of plant sample. The assay is based on ascorbic acid-Fe-EDTA model of $\mathrm{OH}$ radical generating system. The LPE fraction exhibited good scavenging activity with minimum $\mathrm{IC}_{50}$. With TPC and TFC, a significant correlation was determined indicating good ability of $L$.

Table 3 Correlation of $\mathrm{IC}_{50}$ values of different antioxidant activities of L. pinnatifidum with total phenolic (TPC) and total flavonoid (TFC) contents

\begin{tabular}{lll}
\hline Antioxidant Activity & Correlation $\mathrm{R}^{2}$ & \\
& TPC & TFC \\
\hline DPPH radical scavenging activity & $0.8423^{* *}$ & $0.9231^{* *}$ \\
Hydroxyl radical scavenging activity & $0.9453^{* * *}$ & $0.9677^{* * *}$ \\
Nitric Oxide radical scavenging activity & $0.92^{* *}$ & $0.9414^{* * *}$ \\
Iron chelating assay & $0.8128^{* *}$ & $0.9898^{* * *}$ \\
Reducing power assay & $0.9119^{* *}$ & $0.9775^{* * *}$ \\
Phosphomolybdenum assay & $0.8728^{* *}$ & $0.9019^{* *}$ \\
$\beta-$ carotene bleaching activity & $0.8402^{* *}$ & $0.8906^{* *}$ \\
\hline Column
\end{tabular}

Column with different superscripts are significantly different $* * * p<0.001$, **: $p<0.01$ pinnatifidum to scavenge hydroxyl free radical. In nitric oxide assay pink colour of solution is due to nitrite ions, and element with nitrite quenching potency can stop nitrite ion production by utilizing free oxygen. LPE exhibited highest results compared to other fractions, and correlation was also significant with TFC and TPC. The reason behind this activity is that LPE fraction is rich in phenolics and polyphenolics, and such compounds own effective ability nitrite free radicals quenching.

Ferrozine can chelate quantitatively with $\mathrm{Fe}^{2+}$ to make complex of red colour. This reaction is restricted if another chelating agent is present, leading to decline in colour of ferrozine- $\mathrm{Fe}^{2+}$ complex (red). Quantification of this decline estimates the chelating potency for ferrous ions, to compete with ferrozine. The antioxidants moieties in plant extract make a coordinate composite with metal ions and obstruct transfer of electrons. Hence, oxidation reaction is halted and no more free radicals are generated. In our study, it was observed that LPE displayed highly potent results with lowest $\mathrm{IC}_{50}$.

Potassium ferricyanide reduction method was utilized to determine reducing potency of L. pinnatifidum. Reducing $\mathrm{Fe}\left[(\mathrm{CN})_{6}\right]_{3}$ into $\mathrm{Fe}\left[(\mathrm{CN})_{6}\right]_{2}$ give rise to development of intensed Perl's prussian blue colour complex. LPE fraction displayed the maximum value of reducing power in comparison with ascorbic acid. Observed correlation was significant with TPC and TFC. The total antioxidant assessment depends on reducing process of Molybdic acid by plant extract and generation of coloured (green) phosphate/Molybdenum (V) complex, subsequently, at an acidic $\mathrm{pH}$. Current study revealed that maximum results are exhibited by LPE followed by LPB. Correlation is found to be significant with total phenolic and flavonoid content. In $\beta$-carotene bleaching assay, $\beta$-carotene and linoleic acid classical system is 


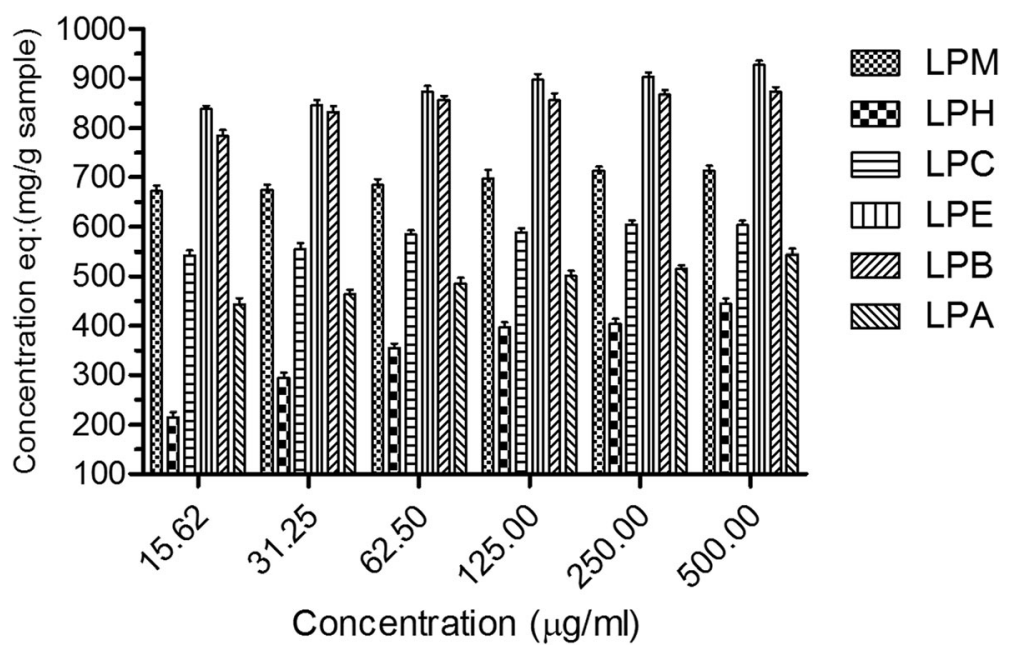

Fig. 6 Total antioxidant assay of L. pinnatifidm methanol extract and its fractions

utilized to evaluate plant extract's antioxidant activity, spectrophotometrically by the virtue of discoloration of $\beta$-carotene. During incubation at $45^{\circ} \mathrm{C}$, a hydrogen atom $(\mathrm{H})$, in diallylic ethylene group of linoleic acid, is removed to generate free radical species of linoleic acid. This specie then attacked on $\beta$-carotene, causing its molecules to be broken down. As a consequence, highly unsaturated $\beta$-carotene molecules lost their chromophore. When antioxidant entities are introduced into the system, linoleate-free radical species are being neutralized and hence affect the extent of $\beta$-carotene oxidation [26]. The antioxidant capacity of plant fractions was correlated with phenolics and flavonoid content. In case of HRS assay highly significant correlation is observed with total phenolics and flavonoids, while other assays also represent substantial correlation with phenolics and flavonoids. This illustrated that plant has a considerable antioxidant potential. Ethyl acetate fraction in our study

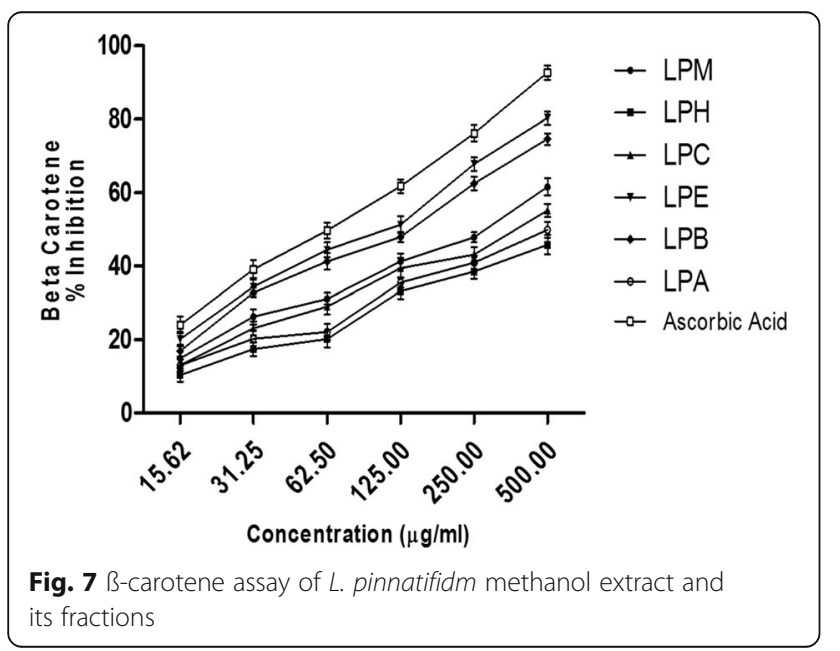

showed highest bleaching reduction potential. Plant's antioxidant repertoire could be owed to the aforementioned lushness in flavonoid and polyphenols. Such compounds are acknowledged by their chemical assembly and redox property, that might have central part in scavenging free radicals and chelating transition metals [27].

Oxidative tension can be overcome through antioxidant species. Such species neutralize the rascal oxidative species as well as repair the cellular damage done by oxidative stress. Food containing phenolics, like polyphenol, is verified source of antioxidant species. And has potent role in combating oxidative stress mediated aberrations [28]. The phenolic species may act by affecting transcription factors including Nuclear factor Erythroid 2 - Related Factor - 2 (Nrf2). Nrf 2, a leucine zipper protein is known for protecting cells in oxidative stress. In oxidative stressed cells Nrf2 binds to antioxidant binding regions of DNA and induce transcription of many cellular defence genes [29]. Dietary supplementation of hydroxy-tyrosol (polyphenol) to mice treated with high fat diet showed decreased oxidative stress in liver. This protective effect attributed to activation of Nrf2 which upregulate antioxidant enzymes [30]. In another study hydroxy-tyrosol recovered anti-oxidant enzymes in adipose tissues, which were depleted after high fat diet administration in mice. An activation of Nrf2 is proposed mechanism in this recovery of antioxidant enzymes [31].

Inflammation is a natural process to cope threats to cellular machinery. In several diseases like rheumatoid arthritis, active hepatitis, sinusitis and many other, use of synthetic anti-inflammatory agent to alleviate severity of these diseases has yielded many side effects. So, natural anti-inflammatory agents are gaining importance. We investigate $L$. pinnatifidum for anti-inflammatory potential. Carrageenan induced edema is commonly used 
Table 4 Effect of L. pinnatifidum on heat induced protein denaturation at $600 \mathrm{~nm}$

\begin{tabular}{|c|c|c|c|c|c|c|}
\hline \multirow[t]{2}{*}{ Treatment } & \multicolumn{5}{|c|}{ \%inhibition of protein denaturation } & \multirow[t]{2}{*}{$\mid \mathrm{C}_{50}(\mu \mathrm{g} / \mathrm{ml}$} \\
\hline & $500 \mu \mathrm{g} / \mathrm{ml}$ & $400 \mu \mathrm{g} / \mathrm{ml}$ & $300 \mu \mathrm{g} / \mathrm{ml}$ & $200 \mu \mathrm{g} / \mathrm{ml}$ & $100 \mu \mathrm{g} / \mathrm{ml}$ & \\
\hline Dic. Pot. & $\begin{array}{l}.13 \pm 0.01 \\
84.70 \pm 1.17^{\mathrm{a}}\end{array}$ & $\begin{array}{l}0.27 \pm 0.01 \\
68.23 \pm 1.17^{\mathrm{a}}\end{array}$ & $\begin{array}{l}0.39 \pm 0.01 \\
54.11 \pm 1.17^{\mathrm{a}}\end{array}$ & $\begin{array}{l}0.45 \pm 0.01 \\
47.05 \pm 1.17^{\mathrm{a}}\end{array}$ & $\begin{array}{l}0.51 \pm 0.01 \\
40 \pm 1.17^{a}\end{array}$ & 186.3 \\
\hline LPM & $\begin{array}{l}0.33 \pm 0.01 \\
61.17 \pm 1.17^{d}\end{array}$ & $\begin{array}{l}0.49 \pm 0.01 \\
42.35 \pm 1.14^{d}\end{array}$ & $\begin{array}{l}0.54 \pm 0.01 \\
36.47 \pm 1.16^{d}\end{array}$ & $\begin{array}{l}0.59 \pm 0.01 \\
30.58 \pm 1.17^{d}\end{array}$ & $\begin{array}{l}0.66 \pm 0.01 \\
22.35 \pm 1.17^{d}\end{array}$ & 436.0 \\
\hline LPH & $\begin{array}{l}0.21 \pm 0.01 \\
75.29 \pm 1.17^{b}\end{array}$ & $\begin{array}{l}0.35 \pm 0.01 \\
58.82 \pm 1.17^{b}\end{array}$ & $\begin{array}{l}0.42 \pm 0.01 \\
50.58 \pm 1.16^{b}\end{array}$ & $\begin{array}{l}0.49 \pm 0.01 \\
42.35 \pm 1.16^{b}\end{array}$ & $\begin{array}{l}0.55 \pm 0.01 \\
35.29 \pm 1.15^{b}\end{array}$ & 237.7 \\
\hline LPC & $\begin{array}{l}0.41 \pm 0.01 \\
51.76 \pm 1.17^{e}\end{array}$ & $\begin{array}{l}0.54 \pm 0.01 \\
36.47 \pm 1.17^{e}\end{array}$ & $\begin{array}{l}0.59 \pm 0.01 \\
30.58 \pm 1.17^{e}\end{array}$ & $\begin{array}{l}0.65 \pm 0.01 \\
23.52 \pm 1.16^{e}\end{array}$ & $\begin{array}{l}0.71 \pm 0.01 \\
16.47 \pm 1.15^{\mathrm{e}}\end{array}$ & 567.5 \\
\hline LPE & $\begin{array}{l}0.27 \pm 0.01 \\
68.23 \pm 1.17 c\end{array}$ & $\begin{array}{l}0.43 \pm 0.01 \\
49.41 \pm 1.17 c\end{array}$ & $\begin{array}{l}0.47 \pm 0.01 \\
44.70 \pm 1.17\end{array}$ & $\begin{array}{l}0.56 \pm 0.01 \\
34.11 \pm 1.17 c\end{array}$ & $\begin{array}{l}0.62 \pm 0.01 \\
27.05 \pm 1.16^{c}\end{array}$ & 333.3 \\
\hline LPB & $\begin{array}{l}0.46 \pm 0.01 \\
45.88 \pm 1.16^{f}\end{array}$ & $\begin{array}{l}0.58 \pm 0.01 \\
31.76 \pm 1.17^{f}\end{array}$ & $\begin{array}{l}0.64 \pm 0.01 \\
24.70 \pm 1.16^{f}\end{array}$ & $\begin{array}{l}0.7 \pm 0.01 \\
17.64 \pm 1.17^{f}\end{array}$ & $\begin{array}{l}0.77 \pm 0.01 \\
9.4 \pm 1.17^{f}\end{array}$ & 621.3 \\
\hline LPA & $\begin{array}{l}0.48 \pm 0.01 \\
43.52 \pm 1.17^{f}\end{array}$ & $\begin{array}{l}0.62 \pm 0.01 \\
27.05 \pm 1.16^{9}\end{array}$ & $\begin{array}{l}0.68 \pm-0.01 \\
20 \pm 1.16^{9}\end{array}$ & $\begin{array}{l}0.72 \pm 0.01 \\
15.29 \pm 1.15^{f}\end{array}$ & $\begin{array}{l}0.82 \pm 0.01 \\
3.5 \pm 1.17^{9}\end{array}$ & 625.5 \\
\hline
\end{tabular}

values shown represent Mean + SD and percentage inhibition at different concentrations; $(n=3)$. Different superscript $\left.{ }^{\mathrm{a}-g}\right)$ indicate significance at $P<0.05$. LPM: $L$ pinnatifidum Methanol extract. LPH: L. pinnatifidum n-Hexane fraction. LPC: L. pinnatifidum Chloroform fraction. LPE: L. pinnatifidum Ethyl acetate fraction. LPB: L. pinnatifidum Butanol fraction. LPA: L. pinnatifidum Aqueous fraction

Table 5 Effect of L. pinnatifidum on carrageenan-induced paw edema in rats

\begin{tabular}{|c|c|c|c|c|}
\hline \multirow[t]{2}{*}{ Treatment } & \multicolumn{4}{|c|}{ Edema formation to \%inhibition } \\
\hline & $1 \mathrm{~h}$ & $2 \mathrm{~h}$ & $3 \mathrm{~h}$ & $4 \mathrm{~h}$ \\
\hline Dic. Pot. $(10 \mathrm{mg} / \mathrm{kg})$ & $\begin{array}{l}0.777 \pm 0.033 \\
23.702 \pm 3.291^{f g h i}\end{array}$ & $\begin{array}{l}0.594 \pm 0.064 \\
24.910 \pm 8.118^{\mathrm{e}}\end{array}$ & $\begin{array}{l}0.481 \pm 0.044 \\
45.819 \pm 4.966^{d e}\end{array}$ & $\begin{array}{l}0.12 \pm 0.027 \\
81.081 \pm 4.269^{a}\end{array}$ \\
\hline LPM (400 mg/kg) & $\begin{array}{l}0.671 \pm 0.047 \\
34.018 \pm 4.654^{\mathrm{bcd}}\end{array}$ & $\begin{array}{l}0.455 \pm 0.043 \\
42.419 \pm 5.500^{b c}\end{array}$ & $\begin{array}{l}0.38 \pm 0.050 \\
57.234 \pm 5.664^{b c}\end{array}$ & $\begin{array}{l}0.175 \pm 0.015 \\
72.297 \pm 2.385^{\mathrm{abc}}\end{array}$ \\
\hline LPM (200 mg/kg) & $\begin{array}{l}0.68 \pm 0.033 \\
33.240 \pm 3.305^{\text {cde }}\end{array}$ & $\begin{array}{l}0.484 \pm 0.022 \\
38.808 \pm 2.811^{\mathrm{cd}}\end{array}$ & $\begin{array}{l}0.464 \pm 0.035 \\
47.749 \pm 3.997^{\text {de }}\end{array}$ & $\begin{array}{l}0.267 \pm 0.021 \\
57.882 \pm 3.370^{\text {def }}\end{array}$ \\
\hline LPH (400 mg/kg) & $\begin{array}{l}0.563 \pm 0.048 \\
44.642 \pm 4.712^{\mathrm{a}}\end{array}$ & $\begin{array}{l}0.355 \pm 0.030 \\
55.108 \pm 3.837^{\mathrm{a}}\end{array}$ & $\begin{array}{l}0.245 \pm 0.027 \\
72.395 \pm 3.140^{a}\end{array}$ & $\begin{array}{l}0.125 \pm 0.067 \\
80.247 \pm 10.629^{a}\end{array}$ \\
\hline LPH (200 mg/kg) & $\begin{array}{l}0.595 \pm 0.011 \\
41.514 \pm 1.113^{\mathrm{ab}}\end{array}$ & $\begin{array}{l}0.422 \pm 0.013 \\
46.570 \pm 1.743^{\mathrm{abc}}\end{array}$ & $\begin{array}{l}0.375 \pm 0.013 \\
57.717 \pm 1.572^{\mathrm{bc}}\end{array}$ & $\begin{array}{l}0.197 \pm 0.024 \\
68.918 \pm 3.831^{b c}\end{array}$ \\
\hline LPC (400 mg/kg) & $\begin{array}{l}0.705 \pm 0.027 \\
30.715 \pm 2.709^{\text {def }}\end{array}$ & $\begin{array}{l}0.48 \pm 0.02 \\
39.350 \pm 2.527^{\mathrm{cd}}\end{array}$ & $\begin{array}{l}0.418 \pm 0.032 \\
52.893 \pm 3.642^{c d}\end{array}$ & $\begin{array}{l}0.2 \pm 0.032 \\
68.468 \pm 5.149^{b c}\end{array}$ \\
\hline LPC (200 mg/kg) & $\begin{array}{l}0.751 \pm 0.033 \\
26.227 \pm 3.325^{\mathrm{efg}}\end{array}$ & $\begin{array}{l}0.541 \pm 0.027 \\
31.588 \pm 3.531^{\text {de }}\end{array}$ & $\begin{array}{l}0.522 \pm 0.043 \\
41.157 \pm 4.893^{\mathrm{ef}}\end{array}$ & $\begin{array}{l}0.3 \pm 0.020 \\
52.702 \pm 3.281^{\mathrm{ef}}\end{array}$ \\
\hline LPE (400 mg/kg) & $\begin{array}{l}0.598 \pm 0.031 \\
41.234 \pm 3.074^{\mathrm{ab}}\end{array}$ & $\begin{array}{l}0.392 \pm 0.019 \\
50.361 \pm 2.496^{\mathrm{ab}}\end{array}$ & $\begin{array}{l}0.317 \pm 0.053 \\
64.308 \pm 6.050^{\mathrm{ab}}\end{array}$ & $\begin{array}{l}0.15 \pm 0.043 \\
76.351 \pm 6.811^{\mathrm{ab}}\end{array}$ \\
\hline LPE (200 mg/kg) & $\begin{array}{l}0.628 \pm 0.060 \\
38.289 \pm 5.929^{a b c}\end{array}$ & $\begin{array}{l}0.461 \pm 0.044 \\
41.696 \pm 5.623^{b c}\end{array}$ & $\begin{array}{l}0.434 \pm 0.038 \\
51.125 \pm 4.351^{\mathrm{cd}}\end{array}$ & $\begin{array}{l}0.23 \pm 0.036 \\
63.738 \pm 5.756^{\mathrm{cd}}\end{array}$ \\
\hline LPB (400 mg/kg) & $\begin{array}{l}0.761 \pm 0.040 \\
25.245 \pm 3.985^{\mathrm{fgh}}\end{array}$ & $\begin{array}{l}0.494 \pm 0.042 \\
37.545 \pm 5.353^{c d}\end{array}$ & $\begin{array}{l}0.474 \pm 0.036 \\
46.623 \pm 4.102^{\text {de }}\end{array}$ & $\begin{array}{l}0.237 \pm 0.029 \\
62.612 \pm 4.615^{\text {cde }}\end{array}$ \\
\hline LPB (200 mg/kg) & $\begin{array}{l}0.788 \pm 0.035 \\
22.580 \pm 3.513^{g h i}\end{array}$ & $\begin{array}{l}0.574 \pm 0.034 \\
27.436 \pm 4.368^{e}\end{array}$ & $\begin{array}{l}0.558 \pm 0.027 \\
37.138 \pm 3.077^{f g}\end{array}$ & $\begin{array}{l}0.33 \pm 0.021 \\
47.972 \pm 3.405^{\mathrm{fg}}\end{array}$ \\
\hline $\begin{array}{l}\text { LPA } \\
(400 \text { mg/kg) }\end{array}$ & $\begin{array}{l}0.801 \pm 0.046 \\
21.318 \pm 4.584\end{array}$ & $\begin{array}{l}0.541 \pm 0.022 \\
31.588 \pm 2.865^{\text {de }}\end{array}$ & $\begin{array}{l}0.531 \pm 0.026 \\
40.192 \pm 3.007^{\mathrm{ef}}\end{array}$ & $\begin{array}{l}0.27 \pm 0.020 \\
57.432 \pm 3.281^{\text {def }}\end{array}$ \\
\hline LPA (200 mg/kg) & $\begin{array}{l}0.852 \pm 0.031 \\
16.269 \pm 3.089^{i}\end{array}$ & $\begin{array}{l}0.612 \pm 0.036 \\
22.563 \pm 4.597^{e}\end{array}$ & $\begin{array}{l}0.61 \pm 0.037 \\
31.350 \pm 4.210^{9}\end{array}$ & $\begin{array}{l}0.368 \pm 0.030 \\
41.891 \pm 4.853^{\mathrm{g}}\end{array}$ \\
\hline
\end{tabular}

Data values shown represent Mean \pm SD and percentage inhibition at different concentrations; $(n=7)$. Different superscript $\left(^{\mathrm{a}-\mathrm{i}}\right)$ indicate significance at $P<0.05$. LPM: L. pinnatifidum Methanol fraction. LPH: L. pinnatifidum n-Hexane fraction. LPC: L. pinnatifidum Chloroform fraction. LPE: L. pinnatifidum Ethyl acetate fraction. LPB: L. pinnatifidum Butanol fraction. LPA: L. pinnatifidum Aqueous fraction 
protocol for detection of anti-inflammatory potential in drugs and plant extracts. Inducer injection cause the migration of leukocytes at target site. It showed its synergetic behaviour with inflammatory mediators such as histamine, bradykinin etc. Basically, it's a biphasic mechanism of approximately 1-5 h. Initial event involved the formation of non-phagocytized edema, and release of histamine and bradykinin, proceeded to second phased excess production of prostaglandins and increased edema formation that may last for $4-6 \mathrm{~h}$. L. pinnatifidum in present study revealed noticeable anti-inflammatory activity by its different fractions. LPH and LPE showed remarkable anti-inflammatory activity and this anti-oedematous activity might be due to its inhibitory potential on proinflammatory mediator's release or synthesis. The antiinflammatory action of L. pinnatifidum in phase- 1 could be owed to possible clampdown of histamine signalling by mast cells stabilizing activity [32]. Inhibiting histamine h1 receptor as well as histidine decarboxylase transcription are also important in anti inflammatory action [33]. In phase-2 anti inflammatory action of extract increases and reaches its supreme at $6 \mathrm{~h}$. This can be explained by probable inhibition of release and / or synthesis of lipoxygenase or cyclooxygenase (COX-2) products by the $L$. pinnatifidum extract. Cyclooxygenase is important to convert arachidonic acid into prostaglandin, by stimulation of several pro-inflammatory cytokines in 2nd inflammatory stage of carrageenan induced edema model [34].

Anti inflammatory action of $L$. pinnatifidum extract appears to be thoroughly correlated with richness in polyphenolic ingredients. Indeed, flavonoids have been known as compelling inhibitors of proinflammatory cytokines and cyclooxygenase, in several previous studies [34]. This action might be through changes of transcription factors level including $\mathrm{Nu}$ clear Factor Kappa B (NF-kB). It is a known oxidative stress marker. It also induces expression of pro inflammatory genes. A study showed that down regulation of NF-kB and other proinflammatory cytokines can yield to normalization of aberrant condition [35].

Peroxisomes proliferator activated receptors (PPARs) are transcription factors and important in inhibiting inflammatory cytokines. These are also involved in glucose and fatty acid metabolism. A study revealed that activation of PPARs lead to improvement in mitochondrial functioning, which was disturbed by oxidative stress and inflammation. Under inflammatory conditions mitochondrial biogenesis is suffered. PPARs normalize this tension by activation of citrate synthase and mitochondrial complex I and II activity [36]. They have role in downregulation of inflammatory genes [37], and are upregulated by polyphenols present in diet [38]. So the role of polyphenols is quite established in combating oxidative stress and chronic inflammation. A plant rich in such bio active compounds is of great importance as a safe alternative to synthetic therapeutic agents.

\section{Conclusion}

Current study recommended that occurrence of polyphenols and flavonoids along with other bio active ingredients might leads to the strong antioxidant profile and consequently lower down the inflammation inducing intermediaries. This study recommended a timely need of further pharmacokinetic analysis, characterization and purification of $L$. pinnatifidum extract for more effective drug designing.

\section{Abbreviations}

AA: Ascorbic acid; ROS: Reactive oxygen species; LPA: Aqueous fraction of LPM; LPB: Butanol fraction of LPM; LPC: Chloroform fraction of LPM; LPE: Ethyl acetate fraction of LPM; LPH: N-hexane fraction of LPM; LPM: $L$. pinnatifidum methanol extract; TFC: Total flavonoid content; TPC: Total phenolic content; D.W: Distilled water; Soln: Solution; h: hour

\section{Acknowledgements}

We acknowledged Prof. Dr. Muhammad Rashid Khan, intensely, for his generous supervision and substantial facilitations of required materials and equipment.

\section{Consent of publication \\ Not applicable in this study.}

\section{Authors' contributions}

MA, SB and HFH carried out collection of plant material, extract preparation and experimental work. SB wrote the manuscript. MRK invigilate, analysed and supervised the entire study. All authors read and approved the final manuscript.

\section{Funding}

The research was carried as partial fulfilment of degree and is not funded by any foreign source.

Availability of data and materials

The data sets analysed during current study are available from corresponding author on reasonable request.

\section{Ethics approval}

This study makes use of rats (Rattus novergicus), and the experimental protocol for the use of animal was approved by the ethical board of Quaid-iAzamUniversity, Islamabad Pakistan.

\section{Competing interests}

The authors declare that they have no competing interest.

Received: 14 June 2019 Accepted: 6 April 2020

Published online: 15 April 2020

References

1. Nagmoti DM, Khatri DK, Juvekar PR, Juvekar AR. Antioxidant activity free radical-scavenging potential of Pithecellobium dulce Benth seed extracts. Free Radic Antioxid. 2012;2(2):37-43.

2. Kim YW, Byzova TV. Oxidative stress in angiogenesis and vascular disease. Blood. 2014;123(5):625-31.

3. Agarwal A, Aponte-Mellado A, Premkumar BJ, Shaman A, Gupta S. The effects of oxidative stress on female reproduction: a review. Reprod Biol Endocrinol. 2012;10(1):49.

4. Forman HJ, Davies KJ, Ursini F. How do nutritional antioxidants really work: nucleophilic tone and Para-hormesis versus free radical scavenging in vivo. Free Radic Biol Med. 2014;66:24-35. 
5. Scrivo R, Vasile M, Bartosiewicz I, Valesini G. Inflammation as "common soil" of the multifactorial diseases. Autoimmun Rev. 2011;10(7):369-74.

6. Parsaei P, Bahmani M, Karimi M, Naghdi N, Asadi-Samani M, Rafieian-Kopaei M. A review of analgesic medicinal plants in Iran. Pharm Lett. 2016;8(2):43-51.

7. Chatterjee C, Mandal G, Mukhopadhyay K, Das S, Mukherjee S, Chatterjee M. Evaluation of analgesic activity of Methanolic extract of Bougainvillea spectabilis leaves in experimental animal models. Ann Int Med Dental Res. 2016;2(5):1.

8. Mahmood A, Mahmood A, Mujtaba G, Mumtaz MS, Kayani WK, Khan MA. Indigenous medicinal knowledge of common plants from district Kotli Azad Jammu and Kashmir Pakistan. J Med Plant Res. 2012;6(35):4961-7.

9. Baba SA, Malik SA. Determination of total phenolic and flavonoid content, antimicrobial and antioxidant activity of a root extract of Arisaema jacquemontii Blume. J Taibah Univ Sci. 2015;9(4):449-54.

10. Alam MN, Bristi NJ, Rafiquzzaman M. Review on in vivo and in vitro methods evaluation of antioxidant activity. Saudi Pharm J. 2013;21(2):143-52.

11. Choi JS, Lim HK, Lee Kl, Hwang IT. Aqueous fraction of cucumber plant extract detoxifies Paraquat Phytotoxicity as a superoxide scavenger. J Food Process Preserv. 2017;41(1):e12864.

12. Anu G, Usha P. Phytochemical screening and in vitro antioxidant study of chloroform soluble fraction of Thespesia populnea bark extract. J Lives Sci. 2017:8:77-80.

13. Karatoprak GŞ, Ilgün S, Koşar M. Antioxidant properties and phenolic composition of Salvia virgata Jacq. Turk J Pharm Sci. 2016;13:201-12.

14. Phatak RS, Hendre AS. Total antioxidant capacity (TAC) of fresh leaves of Kalanchoe pinnata. J Pharm Phytochemistry. 2014 Jan;1:2(5).

15. Hossain MA, Shah MD. A study on the total phenols content and antioxidant activity of essential oil and different solvent extracts of endemic plant Merremia borneensis. Arab J Chem. 2015;8(1):66-71.

16. Hatami T, Emami SA, Miraghaee SS, Mojarrab M. Total phenolic contents and antioxidant activities of different extracts and fractions from the aerial parts of Artemisia biennis Willd. Iran J Pharm Res. 2014;13(2):551.

17. Kulkarni A, Govindappa M, Chandrappa CP, Ramachandra YL, Koka PS. Phytochemical analysis of Cassia fistula and its in vitro antimicrobial, antioxidant and anti-inflammatory activities. Adv Med Plant Res. 2015;3(1):8-17.

18. Afsar T, Khan MR, Razak S, Ullah S, Mirza B. Antipyretic, anti-inflammatory and analgesic activity of Acacia hydaspica R. Parker and its phytochemical analysis. BMC Complement Altern Med. 2015;15(1):136.

19. Wink M. Modes of action of herbal medicines and plant secondary metabolites. Medicines. 2015;2(3):251-86.

20. Shahidi F, Ambigaipalan P. Phenolics and polyphenolics in foods, beverages and spices: antioxidant activity and health effects-a review. J Funct Foods. 2015;18:820-97.

21. Sahreen S, Khan MR, Khan RA. Evaluation of antioxidant activities of various solvent extracts of Carissa opaca fruits. Food Chem. 2010;122(4):1205-11.

22. Jan S, Khan MR, Rashid U, Bokhari J. Assessment of antioxidant potential, total phenolics and flavonoids of different solvent fractions of Monotheca buxifolia fruit. Osong Public Health Res Perspect. 2013;4(5):246-54.

23. Eddy NB, Leimbach D. Synthetic analgesics. II. Dithienylbutenyl-and dithienylbutylamines. J Pharmacol Exp Ther. 1953;107(3):385-93.

24. Khan MA, Rahman AA, Islam S, Khandokhar P, Parvin S, Islam MB, et al. A comparative study on the antioxidant activity of methanolic extracts from different parts of Morus alba L. (Moraceae). BMC Res Notes. 2013;6(1):24.

25. Arulpriya $P$, Lalitha $P$, Hemalatha $S$. Antimicrobial testing of the extracts of Samanea saman (Jacq.) Merr. Der Pharm Chem. 2010;2(6):78-83.

26. Sowndhararajan K, Kang SC. Free radical scavenging activity from different extracts of leaves of Bauhinia vahlii Wight \& Arn. Saudi Jf Biol Sci. 2013;20(4):319-25.

27. See I, Ee GC, Mah SH, Jong VY, Teh SS. Effect of solvents on phytochemical concentrations and antioxidant activity of Garcinia benthamiana stem bark extracts. Int J Geogr Inf Syst. 2017;23(2):117-27.

28. Soto-Alarcon SA, Valenzuela R, Valenzuela A, Videla LA. Liver protective effects of extra virgin olive oil: interaction between its chemical composition and the cell-signaling pathways involved in protection. Endocr Metab Immune Disord-Drug Targets. 2018;18(1):75-84.

29. Wang $X$, Ye $X L$, Liu $R$, Chen $H L$, Bai $H$, Liang $X$, et al. Antioxidant activities of oleanolic acid in vitro: possible role of Nrf2 and MAP kinases. Chem Biol Interact. 2010 Mar 30;184(3):328-37.

30. Valenzuela R, Illesca P, Echeverría F, Espinosa A, Rincón-Cervera MÁ, Ortiz M, et al. Molecular adaptations underlying the beneficial effects of hydroxytyrosol in the pathogenic alterations induced by a high-fat diet in mouse liver: PPAR- $a$ and Nrf2 activation, and NF-KB down-regulation. Food Funct. 2017;8(4):1526-37.
31. Illesca P, Valenzuela R, Espinosa A, Echeverría F, Soto-Alarcon S, Ortiz M, et al. Hydroxytyrosol supplementation ameliorates the metabolic disturbances in white adipose tissue from mice fed a high-fat diet through recovery of transcription factors Nrf2, SREBP-1C, PPAR- $\gamma$ and NF-KB. Biomed Pharmacother. 2019;109:2472-81.

32. Mohamed AA, Khalil AA, El-Beltagi HE. Antioxidant and antimicrobial properties of kaff maryam (Anastatica hierochuntica) and doum palm (Hyphaene thebaica). Grasas Aceites. 2010;61(1):67-75.

33. Shashidhara S, Bhandarkar AV, Deepak M. Comparative evaluation of successive extracts of leaf and stem bark of Albizzia lebbeck for mast cell stabilization activity. Fitoterapia. 2008;79(4):301-2.

34. Fawole OA, Ndhlala AR, Amoo SO, Finnie JF, Van Staden J. Antiinflammatory and phytochemical properties of twelve medicinal plants used for treating gastro-intestinal ailments in South Africa. J Ethnopharmacol. 2009;123(2):237-43.

35. Hernández-Rodas MC, Valenzuela R, Echeverría F, Rincón-Cervera MÁ, Espinosa A, Illesca P, et al. Supplementation with docosahexaenoic acid and extra virgin olive oil prevents liver steatosis induced by a high-fat diet in mice through PPAR- $a$ and Nrf2 upregulation with concomitant SREBP-1C and NF-kB downregulation. Mol Nutr Food Res. 2017;61(12):1700479.

36. Barrera C, Valenzuela R, Rincón MÁ, Espinosa A, Echeverria F, Romero N, et al. Molecular mechanisms related to the hepatoprotective effects of antioxidant-rich extra virgin olive oil supplementation in rats subjected to short-term iron administration. Free Radic Biol Med. 2018:126:313-21.

37. Berghe W, Vermeulen L, Delerive P, De Bosscher K, Staels B, Haegeman G. A paradigm for gene regulation: inflammation, NF-KB and PPAR. In: Peroxisomal disorders and regulation of genes. Boston: Springer; 2003. p. 181-96.

38. Domínquez-Avila JA, González-Aguilar GA, Alvarez-Parrilla E, De la Rosa LA. Modulation of PPAR expression and activity in response to polyphenolic compounds in high fat diets. Int J Mol Sci. 2016;17(7):1002.

\section{Publisher's Note}

Springer Nature remains neutral with regard to jurisdictional claims in published maps and institutional affiliations.

\section{Submit your manuscript to a SpringerOpen ${ }^{\circ}$ journal and benefit from:}

- Convenient online submission

- Rigorous peer review

- Open access: articles freely available online

High visibility within the field

- Retaining the copyright to your article

Submit your next manuscript at $>$ springeropen.com 